\title{
COMMENTS
}

\section{JURISDICTION OVER CIVILIANS UNDER ARTICLE 3(A) OF THE UNIFORM CODE OF MILITARY JUSTICE- THE TOTH CASE}

Article 3(a) of the Uniform Code of Military Justice permits persons charged with having committed offenses while in a status subject to the Code to be tried by courts-martial even after such status has been terminated. ${ }^{1}$ Toth $v$. Talbott, ${ }^{2}$ the first test of Article 3(a), raises important questions with respect to the extent of the power of Congress to impose courts-martial upon civilians. ${ }^{3}$ Robert Toth, honorably discharged from the Air Force five months previously, was arrested in Pittsburgh by military police and immediately flown to Andrews Field, Maryland, where he was ordered into military uniform. Soon thereafter he was transported by military aircraft to Korea for trial by court-martial on a charge of having murdered a Korean citizen. Before trial, the District Court for the District of Columbia granted a petition for a writ of habeas corpus on the ground that his arrest was without statutory authorization. ${ }^{4}$ Pursuant to court order the Air Force returned Toth to the United States. The District Court then ordered his release, modifying its prior opinion to hold that even if arrest of a civilian were authorized, the Air Force was not empowered to transport him to a distant point for trial. ${ }^{5}$

Insofar as it is based upon a lack of statutory authorization to apprehend and remove accused persons for trial, the Toth release order seems unjustified. Jurisdiction to try all offenses under the Code, punishable by confinement for five years or more, is conferred upon courts-martial by Article 3(a), except when the accused can be tried for the offense in the federal courts. ${ }^{6}$ Military personnel

164 Stat. 109 (1950), 50 U.S.C.A. § 553(a) (1950): "Subject to the provisions of article 43, any person charged with having committed, while in a status in which he was subject to this code, an offense against this code, punishable by confinement of five years or more and for which the person cannot be tried in the courts of the United States or any State or Territory thereof or of the District of Columbia, shall not be relieved from amenability to trial by courts-martial by reason of the termination of said status."

2113 F. Supp. 330 (D. D.C., 1953); noted in 22 Geo. Wash. L. Rev. 115 (1953).

${ }^{3}$ It should be noted that under Articles 2(10) and 2(11), 62 Stat. 109 (1950), 50 U.S.C.A. $\$ \$ 552(10), 552(11)$, certain civilians are subject to the Code. When the convenient terminology "discharged serviceman" is used in the text, it refers also to this category of persons.

113 F. Supp. 330 (D. D.C., 1953).

5114 F. Supp. 468 (D. D.C., 1953).

${ }^{8}$ Accused persons.are not triable in the federal courts for offenses against the Code such as desertion, insubordination, dereliction of duty, even though the offense be committed within the United States or its territories. 
designated by regulations are empowered by Article 7(b) to apprehend persons subject to courts-martial. ${ }^{7}$ Servicemen can be confined and transported from one place to another for court-martial trial. ${ }^{8}$ There is little in the Code to suggest that persons subject to Article 3(a) should be afforded treatment different from that given members of the armed services. ${ }^{9}$ It would seem, therefore, that unless Article 3(a) failed to reflect congressional intent, Congress considered the due process guaranteed to members of the military service ${ }^{10}$ the only requisile protection to persons formerly subject to military law.

If the legality of Toth's detention and transportation could be tested in a military proceeding, issuance of the writ before trial would appear to be improper. The availability of habeas corpus hinges in large measure on the stage of the proceedings at which it is requested. ${ }^{11}$ The Supreme Court has consistently held that the usual remedies available must be exhausted before a writ may issue. "[T]he hearing on habeas corpus is not ... intended as a substitute for the functions of the trial court."12 Courts-martial and the military reviewing authorities are competent to consider questions of "military due process."13 Since the civil courts should not assume that they would refuse to do so, ${ }^{14}$ it is doubtful

764 Stat. 111 (1950), 50 U.S.C.A. §561(b) (1950).

${ }^{8}$ Article 5, 64 Stat. $110^{\circ}(1950), 50$ U.S.C.A. $\$ 555$ (1950) reads: "This chapter shall be applicable in all places." Airman $1 / \mathrm{c}$ Thomas Kinder, a co-defendant in the court-martial, was ordered to Korea from an air station in Wisconsin, N.Y. Times, p. 4, col. 4 (May 26, 1953).

- The forerunners of Article 3(a) were Article of War 94, 41 Stat. 805 (1920), 10 U.S.C.A. $\$ 1506$ (1940), and Article 14 (11th) of the Articles for the Government of the Navy, Rev. Stat. $\$ 1624$ (1878), 34 U.S.C.A. $\$ 1200(1940)$. Both state that discharged persons shall be amenable to military jurisdiction "in the same manner and to the same extent as if [they] had not received such discharge" while Article 3(a) states that such persons "shall not be relieved of amenability to trial by courts-martial..." If this alteration of wording indicates no intended substantive change, persons tried under Article $3(\bar{a})$ should be dealt with "in the same manner" as members of the armed services. Legislative history is not helpful as to the reason for the change, in itself evidence perhaps that Article 3(a) was "new in format more than in anything else." Hearings before the Subcommittee of the House Commiltee on the Armed Services, 81st Cong. 1st Sess. 902 (1949). It should be noted, however, that it is not clear that persons held for trial under Article 3(a) are subject to courts-martial for offenses committed while so held. Article 2 fails to mention them in enumerating persons subject to the Code. Furthermore, Article 3(b) provides that persons charged with having oldained fraudulent discharge are subject to the Code while awaiting trial. These provisions might permit an inference that failure so to provide in Article 3(a) means that persons apprehended under 3(a) are not subject to court martial trial for offenses committed while held. But it seems inconceivable that Congress intended to confer jurisdiction and so limit the authority of the military. Cf. Kahn v. Anderson, 255 U.S. 1 (1921).

10 For discussion of "military due process" and its distinction from civilian due process, see United States v. Clay, 1 U.S.C.M.A. 74, 1 C.M.R. 74 (1951). Consult Wurfel, "Military Due Process": What Is It?, 6 Vand. L. Rev. 251 (1953).

${ }^{11}$ Dissent of Mr. Justice Frankfurter, Sunal v. Large, 332 U.S. 174, 185 (1947).

12 Henry v. Henkel, 235 U.S. 219, 229 (1914).

${ }^{13}$ "The military courts, like the state courts, have the same responsibilities as do the federal courts to protect a person from violation of his constitutional rights." Burns v. Wilson, 346 U.S. 137, 142 (1953); United States v. Clay, 1 U.S.C.M.A. 74, 1 C.M.R. 74 (1951).

1" Burns v. Wilson, 346 U.S. 137 (1953), rehearing denied 346 U.S. 844 (1953). 
that a writ should have issued at this stage in the proceeding except on the jurisdictional ground that Toth's constitutional guarantees as a civilian were violated by Article 3(a)..$^{15}$

This comment will first consider whether "military due process" meets the requirements of "civilian due process." This issue raises questions concerning the constitutionality of Article 3(a) in its present form, and the extent of congressional power to subject civilians to military trial.

\section{I}

The due process problem which the Toth case poses is twofold, but there is no serious question of non-compliance with the statutory protections furnished by the Code. Toth seems to have been afforded "military due process." 16 There remains the question of what due process is constitutionally requisite to the taking of jurisdiction over civilians no longer associated with the military. Civilians arrested and held for trial under Article 3(a) have in effect been reinducted for a limited purpose into the armed services. A charge brought by the apprehending and prosecuting authority is sufficient under the Code to effect the change from civilian to military status. ${ }^{27}$

It cannot be maintained that this change of status is of minor significance. The content of "due process" differs substantially in the military and civilian contexts. ${ }^{18}$ Court-martial is a command rather than a judicial function, ${ }^{19}$ and

${ }^{15}$ Petition for writ of habeas corpus may be brought before trial. E.g., Mahan v. Justice, 127 U.S. 700 (1888); Ex parte Royal, 117 U.S. 241, 245 (1886). Cf. 62 Stat. 967, 28 U.S.C.A. $\$ 2255$, which provides in part: "An application for a writ of habeas corpus . . . shall not be entertained... unless it appears... that the remedy by motion is inadequate or ineffective to test the legality of detention." It does not seem that military tribunals are appropriate forums to test the constitutionality of a statute. Flannery v. Commanding General, 69 F. Supp. 661 (S.D. N.Y., 1946), rev'd on appeal by stipulation of the parties, C.A. 2d, April 18, 1946, Order No. 20235 (unpublished). Snedeker, Habeas Corpus and Court Martial Prisoners, 6 Vand. I. Rev. 288 (1953). In any event, review of decisions by the Court of Military Appeals is obtainable only by collateral attack. Shaw v. United States, 209 F. 2d 298 (App. D.C., 1954). See In re Yamashita, 327 U.S. 1, 8 (1946). The trial court should, therefore, be permitted in the exercise of its discretion to grant the writ before trial. Military Jurisdiction over Discharged Servicemen: Constitutionality and Judicial Protection, 67 Harv. L. Rev. 479, 487 (1953). But see Gusik v. Shilder, 340 U.S. 128 (1950); but cf. Sweeney v. Woodall, 344 U.S. 86 (1952); cf. United States v. Frantz, 2 U.S.C.M.A. 161, 7 C.M.R. 37 (1953), where the Court of Military Appeals considered the constitutionality of Article 134 of the Code.

${ }^{16}$ But consult N.Y. Times, $\S 4$, p. 2, col. 7 (May 31, 1953), pointing out that Toth was flown to Korea without benefit of counsel; ibid., p. 14, col. 2 (June 27, 1953), stating that he had been handcuffed, forced into uniform; and ibid., p. 1, col. 5 (May 28, 1953), which quoted Toth as saying 1) he was not in handcuffs and was being well treated and 2) he had been told of his right to civilian counsel but could not afford legal fees.

- 17 Court-martial jurisdiction is dependent on the military status of the accused. United States v. Grimley, 137 U.S. 157 (1890); and once discharge has taken place cancellation or revocation of that discharge by unilateral action cannot effect alteration of civilian status, Snedeker, Jurisdiction of Naval Courts Martial over Civilians, 24 Notre Dame Lawyer 490, 522 (1949), and cases there cited.

18 Op. cit. supra note 10.

${ }^{19}$ Winthrop, 1 Military Law and Precedents (2d ed., 1896), at 54: "[Courts-martial] are in fact simply instrumentalities of the executive power, provided by Congress for the President 
persons subject thereto have no right to the Fifth and Sixth Amendment guarantees of indictment and trial by jury. ${ }^{20}$ Although the Code provides some measure of protection in requiring pretrial investigation, ${ }^{21}$ notice, ${ }^{22}$ and appointment of counsel, ${ }^{23}$ the extent of non-compliance with these statutory protections necessary to vitiate a conviction remains unclear. ${ }^{24}$

Moreover, the scope of review by civil courts available to the military prisoner is surprisingly unsettled. ${ }^{25}$ The writ of habeas corpus is the primary method for challenging in the civil courts the actions of a military tribunal. ${ }^{26}$ It has long been established that on habeas corpus a court may inquire into the "jurisdiction" of a sentencing tribunal. But there are at least two concepts of "jurisdiction": "a narrow concept . . . under which the only facets of the court martial into which the civil courts may inquire are whether the defendant was subject to military law, whether the offense was cognizable by court martial, whether the tribunal was properly convened, and whether the sentence was within its authority to impose"; ${ }^{27}$ and a broad concept similar to the review of state convictions, under which inquiry can be made into the fundamental fairness of the proceedings, arguably made requisite by the constitutional guarantee of due process. ${ }^{28}$

The Supreme Court in Hiatt v. Brown ${ }^{29}$ reasserted the limitations imposed by the narrow concept of jurisdiction, repudiating the tendency in the lower courts

... to aid him in properly commanding the army and navy and enforcing discipline therein ... a court-martial is not a court ... it is as much subject to the orders of a competent superior as is any military body or person." Cf. Morgan, The Background of the Uniform Code of Military Justice, 6 Vand. L. Rev. 169 (1953).

${ }^{20}$ Whelchel v. McDonald, 340 U.S. 122 (1950); see Johnson v. Eisenstrager, 339 U.S. 763, 783 (1950).

${ }^{21}$ Article 32, 64 Stat. 118 (1950), 50 U.S.C.A. $\$ 603$ (1950).

2 Tbid., at $\$ \$ 604,606$ (Articles 33, 35).

${ }^{23}$ Ibid., at $\$ 591$ (Article 27).

24 For an extended and detailed discussion of competing interpretations of prejudicial error in the Court of Military Appeals see United States v. Woods, 2 U.S.C.M.A. 203, 8 C.M.R. 3 (1953). Consult Durant v. Hiatt, 81 F. Supp. 948 (D.C. Ga., 1948), aff'd 177 F. 2d 373 (C.A. 5th, 1949), where the Court denied that illegal arrest of an officer in active duty status constituted valid grounds for the issuance of a writ of habeas corpus.

${ }^{25}$ E.g., Due Process in Criminal Courts Martial, 20 Univ. Chi L. Rev. 700, 701 (1953).

${ }^{26}$ Cf. Shapiro v. United States, 69 F. Supp. 205 (Ct. Cl., 1947) (suit for forfeited pay in Court of Claims).

${ }^{27}$ Op. cit. supra note 25 , at 700 .

${ }^{28}$ E.g., Anthony v. Hunter, 71 F. Supp. 823 (D. Kan., 1947).

29339 U.S. 103 (1950). The court-martial included the following errors: (1) conviction of murder on the theory that the defendant was under an obligation to retreat even though he was a sentry on post (had he left his post he could have been court-martialed under Article of War 86); (2) malice or premeditation was not shown; (3) incompetent defense counsel submitted only a token defense. "If the court martial errors found in [Hiatt v. Brown] are to be ignored, it is hard to imagine what would be considered." Op. cit. supra note 25, at 702. 
toward a broader scope of review..$^{30}$ The 1953 case of Burns $v$. Wilson $n^{31}$ suggests that civil courts can determine whether the military fully and fairly considered the due process issue. ${ }^{32}$ Civil courts, under the Burns dictum, can decide the due process issue only if the military did not. Since there has been no military hearing on the due process allegations in the Toth case, it can be argued that under Burns v. Wilson the civil court may inquire fully into compliance with the statutory protections afforded by the Code. ${ }^{33}$ Limiting review to questions not .considered by the military implies, however, that the military court should first have an opportunity to consider these questions. Under the Burns decision a remand to the military is not considered necessary when the military court has failed to consider due process allegations. But this does not indicate that the civil courts will be permitted to thwart the allocation of responsibility to military tribunals by entertaining petitions for writs of habeas corpus before the military can proceed with its regularly constituted hearings. Although the Court of Military Appeals was not established until after the Burns case initially arose, the majority opinion indicates that the Supreme Court was attempting to carve out an area in which the findings of the new reviewing authority would be final.$^{34}$ Since it could not be assumed that the military failed to fully and fairly consider the due process issues, the Supreme Court did not consider it necessary to grant a hearing on the merits of affidavit-supported allegations such as coerced confession, "planted" evidence, denial of counsel, and a trial conducted amid hysteria. ${ }^{35}$ The thrust of the opinion is that the scope of review remains extremely narrow, reinforcing the bifurcation of military and civilian due process. ${ }^{36}$

In view of the significant guarantees and safeguards not available to the citizen in a military status, the unilateral imposition of a change of status seems objectionable. Although some protection is afforded by the provision in the Manual for Courts Martial that "[i]urisdiction under Article 3(a) should not be exercised without the consent of the Secretary of the Department concerned," ${ }^{37}$

${ }^{30}$ E.g., Shapiro v. United States, 69 F. Supp. 205 (Ct. Cl., 1947) (defendant notified of charges eighty minutes before trial); Beets v. Hunter, 75 F. Supp. 825 (D. Kan., 1948) (defendant's counsel incompetent), rev'd for failure to exhaust administrative remedies, $180 \mathrm{~F}$. 2d 101 (C.A. 10th, 1950), cert. denied, 339 U.S. 963 (1950).

31346 U.S. 137 (1953), rehearing denied 346 U.S. 844 (1953). $\quad{ }^{32}$ Ibid., at 142.

${ }^{32}$ Military Jurisdiction Over Discharged Servicemen: Constitutionality and Judicial Protection, 67 Harv. L. Rev. 479, 487 (1953).

${ }^{34}$ Cf. Dobson v. Commissioner, 320 U.S. 489 (1943), where the Supreme Court attempted to.establish a doctrine of judicial review of tax court decisions; Griswold, The Need For a Court of Tax Appeals, 57 Harv. L. Rev. 1153 (1944).

35346 U.S. 137, 143 (1953).

${ }^{33}$ Ibid., dissent by Mr. Justice Douglas, at 154: "The undisputed facts in this case make a prima facie case that our rule on coerced confessions expressed in Watts v. Indiana, 338 U.S. 49 [1948] was violated here."

${ }^{37}$ Manual for Courts Martial, United States, 1951, at 15. 
an executive regulation promulgated to effectuate a grant of statutory authority does not seem on a par with the Federal Rules of Criminal Procedure. Rule 40, for example, furnishes an indication of the necessary components of civilian due process. ${ }^{38}$ Rule 40 provides for a $b i$-party hearing before a commissioner prior to removal to another district for trial when arrest is not preceded by indictment. The charge by the military and the consent of the Secretary has been analogized to the indictment, and consent to removal upon presentation of an indictment has been described as a mere formality. ${ }^{39}$ However, necessary compliance with a prescribed statutory "formality" before removal appears to provide a safeguard not present in executive regulations designed for efficient and politic administration.

Moreover, the limitation of offenses to which Article 3(a) is applicable, and therefore the scope of military jurisdiction, would appear to be within executive discretion. Article 3(a) by its terms applies to offenses punishable by confinement for more than five years. The Code makes no provision for punishment except to prescribe the death penalty for certain offenses. ${ }^{40}$ Rather, the Manual for Courts Martial, an executive regulation, provides that the maximum punishments therein prescribed are only advisory where civilians are concerned. ${ }^{11}$ It is to be "used as a guide, subject to such exceptions as may be deemed warranted for determining the appropriate punishment for such persons." ${ }^{22}$ This would seem to mean that virtually any offense with which a civilian was charged might be punished by more than five years confinement. Furthermore, the maximum punishments provided by the Manual are subject to suspension, presumably on recommendation of the armed forces. ${ }^{43}$ Thus the provision of Article 3(a) limiting the exercise of jurisdiction on the basis of the seriousness of the offense appears to be insubstantial protection against recall of a veteran in virtually any case in which the executive authority deems it appropriate. Another objection to Article 3(a) in its present form serves further to underline the necessity of preliminary hearing in the civil courts. Since Article 3(a) bestows jurisdiction on courts-martial only in cases which "cannot be tried in the courts of the United States or any Territory thereof," the convening officer of the court-martial must, presumably, first determine the jurisdiction of the civil courts. ${ }^{44}$ Not only may this impose unnecessary hardship on an ac-

${ }^{38}$ Fed. Rules Crim. Proc. 40.

"Op. cit. supra note 33 , at 488 .

${ }^{10}$ E.g., Articles 118, 120(a), 64 Stat. 140 (1950), 50 U.S.C.A. $\$ \delta 712,714$ (a) (1950), which provide death sentences for murder and rape.

il Manual for Courts Martial, United States, 1951, at 213.

Ibid.

43 Ibid., 1953 Cum. Pocket Part at 125 (Executive Order suspending limitations on punishments for certain crimes in forces under Commander in Chief, Far East).

"Remarks of Judge Advocate General of the Army, Hearings before the Subcommittee of the Senate Committee on the Armed Forces, 81st Cong. 1st Sess. 256-57 (1949), concerning the inappropriateness of such determination by courts-martial. 
cused, but the doubtful availability of an appropriate civil forum for the presentation of a writ of habeas corpus might deprive the extra-territorial military prisoner of any review by the civil courts. ${ }^{45}$

Article 3(a) seems to stand alone in giving broad discretionary powers to define jurisdiction where access to judicial review is severely limited. Other changes of status, certainly of no greater import, cannot be accomplished merely by the action of the party seeking to make the change. Denaturalization cannot .be effected without court judgment once citizenship has been attained. ${ }^{46}$ The resident alien is entitled to procedural due process in deportation proceedings. ${ }^{47}$ While Congress may provide that the deportation hearing be administrative, ${ }^{48}$ there must be judicial review of its fairness. ${ }^{49}$ Similarly, immigrants are entitled to a fair hearing of their claim to United States citizenship. ${ }^{50}$

Induction into the military service is likewise ineffective until certain formalities have been complied with, and the courts will consider the appropriateness of the procedure to achieve the change of status. ${ }^{51}$ The fact that under Article 3(a) the change from civilian to military status is imposed solely for the purpose of criminal prosecution emphasizes the incongruity of transformation without judicial supervision of the procedure surrounding the change. "[The habeas corpus] remedy may be quite illusory in many instances. ... It requires one first to enter the armed forces and drop every vestige of civil rights. . . . No more drastic condition precedent to judicial review has ever been framed." 52

Congress has recognized the necessity for the protection afforded by preliminary judicial hearing in comparable situations. Section 3185 , Title 18 , of the United States Code provides for the extradition of persons accused of having committed crimes in territories occupied by the United States or under its control. It requires that hearings be held before a court "of the United States only, who shall hold such person on evidence establishing probable cause that he is guilty of the offense charged."

is Wurfel, Military Habeas Corpus, 49 Mich. L. Rev. 493, 520-24 (1951).

${ }^{45}$ Baumgartner v. United States, 322 U.S. 665 (1944); Schneiderman v. United States, 320 U.S. 118 (1943).

47 Jordan v. De George, 341 U.S. 223 (1951); Bridges v. Wixon, 326 U.S. 135 (1945); The Alien and the Constitution, 20 Univ. Chi. L. Rev. 547, 555-56 (1953).

18 United States ex rel. Valjauer v. Commissioner, 273 U.S. 103 (1927).

49 E.g., Ng Fung Ho v. White, 259 U.S. 276 (1922).

${ }^{50}$ Chin Yow v. United States, 208 U.S. 8 (1908).

- 31 E.g., Billings v. Truesdell, 321 U.S. 542 (1944); Estep v. United States, 347 U.S. 114 (1945). Consult Snedeker, Jurisdiction of Naval Courts Martial over Civilians, 24 Notre Dame Lawyer 490, 123-29 (1949): "Without compliance with the authorized formalities, a military status cannot be assumed after the change from military to civilian status has occurred." 4 Ops. Comp. Gen. 777 (1925): "too plain for argument."

${ }_{52}$ Mr. Justice Murphy, concurring in Estep v. United States, 347 U.S. 114, 129-30 (1945).

3362 Stat. 823 (1948), amended 63 Stat. 96 (1949), 19 U.S.C.A. § 3185 (1949). 
ings be public, that the evidence be authenticated, and that the government will bear the expense of producing witnesses if the accused is indigent. ${ }^{54}$

The case against permitting transportation by the military without preliminary hearing is further strengthened by the questionable availability of habeas corpus protection to the extra-territorial military prisoner. Since Toth has been returned to the United States this unsettled question is no longer of vital importance to him. ${ }^{55}$ Moreover, before forceable removal to Korea, Toth was within the jurisdiction of an appropriate tribunal. Habeas corpus is clearly available to persons imprisoned within the United States, ${ }^{56}$ and removal from a district. in which proceedings have commenced will not deprive a court of jurisdiction. ${ }^{57}$ Although no proceedings were brought before Toth's removal, to permit the military authorities to deprive a citizen of the protection of habeas corpus by transporting him swiftly overseas would be to sanction kidnapping. Nevertheless, in considering the constitutionality of Article 3(a) in its present form, it should be remembered that it is doubtful whether a court must entertain as a matter of right the petition of a citizen imprisoned abroad. ${ }^{58}$

Even if the courts and Congress conclude that Article 3(a) need not be eliminated from the Code, the necessity for revision seems clear. The constitutional guarantee of due process of law should prevent the civilian from being deprived of the protection afforded by judicial hearing in cases where a change to military status is at issue. The fundamental question of the power of Congress to extend the jurisdiction of military tribunals remains to be considered.

\section{II}

Congress is empowered by the Constitution to provide and maintain land and naval forces and to make rules for their regulation. ${ }^{59}$ From this authority stems the power to confer jurisdiction in appropriate cases upon courts-martial. By virtue of the Fifth Amendment courts-martial jurisdiction may extend, however, only to "cases arising in the land or naval forces."

${ }^{54} \mathrm{Ibid}$., at $825-26$ and $\$ \$ 3189,3190,3191$.

${ }^{55}$ The government is apparently willing to consider Burns v. Wilson controlling. See note, page 4 of the Brief for Appellant. Government counsel conceded jurisdiction at the district court level. See Brief for Appellant, Joint Appendix, page 21.

s8 62 Stat. 964 (1948), amended 63 Stat. 105 (1949), 28 U.S.C.A. $\$ 2241$ (1949).

${ }^{57}$ Ex parte Endo, 323 U.S. 283 (1944).

${ }^{68}$ In Burns v. Wilson, 346 U.S. 137 (1953), the court assumed without discussion that the District Court for the District of Columbia had jurisdiction to grant a writ sought by American citizens confined in Japan by the military. But jurisdiction assumed sub silento is not binding upon the court. See United States v. Tucker Truck Lines, Inc., 344 U.S. 33, 38 (1952). "We should not permit a question of jurisdiction as far reaching as this one to go by concession, or decide it sub silento. I express no view on how we should determine the issue, . . . but I think we should frankly face it, even at the risk of concluding that a legislative remedy is necessary." Mr. Justice Frankfurter, dissenting from the denial of a rehearing in Burns v.
Wilson, 346 U.S. 844, 852 (1953).

59 U.S. Const. Art. 1, \&8.

${ }^{80}$ U.S. Const. Amend. 5. 
It has been argued by analogy to judicial definition of the word "case" 1 appearing in the judiciary article of the Constitution ${ }^{62}$ that no case arises until proceedings have been instituted against the accused. Article of War 94, superseded by the Code, provided that in cases involving fraud, persons separated from the service would "continue to be liable to be arrested and held for trial and sentence by court martial in the same manner and to the same extent as if [they] had not been so separated therefrom." 63 In extending military jurisdiction .to civilians against whom no proceedings were instituted while they were in military status, Article of War 94 was held to exceed the limits set by the Fifth Amendment. In this case, Flannery v. Commanding General, ${ }^{64}$ a writ of habeas corpus issued on the ground that Article of War 94 violated petitioner's constitutional right to indictment and trial by jury. Although issuance of the writ was reversed by stipulation of the parties, ${ }^{65}$ there exists substantial support for the District Court view. ${ }^{66}$

Nevertheless, a few cases have upheld the constitutionality of Article of War $94 .{ }^{67}$ An early case, In re Bogert, ${ }^{68}$ relied upon selected sentences from a dictum in Ex parte Milligan ${ }^{69}$ to reach the conclusion that under the Fifth Amendment a "case" arose when the offense was committed. But the tenor of the Milligan decision, as well as the dictum relied upon, would seem to support the opposite

${ }^{61}$ Pacific Railway Commission, 32 Fed. 241, 255 (C.C. N.D., 1887), quoting Chief Justice Marshall, Osborn v. Bank of United States, 9 Wheat. 738, 819 (U.S. 1824), and Mr. Justice Story, 2, Story, Commentaries on the Constitution of the United States $\$ 1646$ (5th ed., 1891).

62 U.S. Const. Art. $3, \S 2$.

6341 Stat. 805 (1920), 10 U.S.C.A. $\$ 1566$ (1940).

6469 F. Supp. 661 (S.D. N.Y., 1946).

${ }^{65}$ C.A. 2d, April 18, 1946, Order No. 20235 (unpublished).

${ }^{66}$ Winthrop, Military Law and Precedents 105-7 (1920 ed.); Davis, Treatise on the Military Law of the United States 355 (3rd ed., 1915); De Hart, Military Law 35 (1863); Snedeker, Jurisdiction of Naval Courts Martial over Civilians, 24 Notre Dame Lawyer 490, 528-29 (1949); The Amenability of the Veteran to Military Law, 46 Col. L. Rev. 977 (1946); Curran, Lincoln Conspiracy and Military Jurisdiction over Civilians, 9 Notre Dame Lawyer 26 (1933) (for an interesting historical review of civilian's right to trial in civil courts); Testimony of Robert L'Heureux, Chief Counsel, Senate Banking and Currency Committee, in Hearings before Subcommittee of the House Committee on the Armed Services, 81st Cong. 1st Sess. 818 (1949): "Great constitutional doubt exists as to these provisions"; Testimony of Felix Larkin, ibid., at 881 : "The question I have ... is the constitutionality of attempting to retain a continuing jurisdiction." Cf. Remarks of Senator Morse in Hearings before Subcommittee of the Senate Committee on the Armed Services, 81st Cong. 1st Sess. 81 et seq. (questioning the necessity of excluding constitutional guarantees even where members of services are concerned); debate on the forerunner of Article 3(a), Cong. Globe, 37th Cong. 3rd Sess. (1863) at 954, (Senator Cowan): "There can be no possible necessity that the citizen not in the service shall be subjected to this martial law...."

${ }^{67}$ Kronberg v. Hale, 180 F. 2d 128 (C.A. 9th, 1950), cert. denied 339 U.S. 969 (1950); Terry v. United States, 2 F. Supp. 962 (D. Wash., 1933); Ex parte Joly, 290 Fed. 858 (S.D. N.Y., 1922); In re Bogert, 3 Fed. Cas. 796, No. 1,596 (C.C.D. Cal., 1873).

683 Fed. Cas. 796, No. 1,596 (C.C.D. Cal., 1873).

${ }^{69} 4$ Wall. (U.S.) 2 (1866). 
conclusion: "Everyone connected with those branches of the public service is amenable to the jurisdiction which Congress has created ... and while thus serving, surrenders his right to be tried by the civil courts."70

In Kronberg v. Hale, ${ }^{71}$ the Ninth Circuit Court of Appeals refused to declare Article of War 94 unconstitutional to permit recovery of damages in an action for false imprisonment brought against Matthew Hale, Commanding General of the Fourth Air Force. The decision was based on the long standing existence of Article of War 94, and the absence of any consideration of its constitutionality by the Supreme Court.72

The authority of these cases for the constitutionality of Article of War 94 does not seem compelling. The power of Congress to subject discharged servicemen and certain other civilians to military jurisdiction for offenses committed while subject to military law is still to be definitively settled. Those considerations which should rule such a determination find their source in the reasons for the existence of courts under any circumstances. It seems clear that Article 3(a) cannot be justified by the congressional power to raise armies, ${ }^{73}$ nor by the power to confer jurisdiction on military tribunals for offenses against the law of nations. ${ }^{74}$ The creation of courts-martial and the definition of their jurisdiction is justified by the power of Congress to regulate the armed forces, ${ }^{75}$ but it would seem that Article 3(a) must be shown to bear a reasonable relation to some problem of military discipline.

The discipline necessary to the efficiency of the army and navy, required other and swifter modes of trial than are furnished by the common law courts; and, in pursuance of the power conferred by the Constitution, Congress ... declared the kinds of trial, and the manner in which they shall be conducted, for offenses committed while the party is in the military or naval service. ${ }^{76}$

Article 3(a) appears to have only a tenuous relationship to the justification for courts-martial. The argument that escape of an isolated number of offenders against the Code from punishment by military authorities would have an appreciable effect on discipline ${ }^{77}$ does not seem convincing. After the accused has

${ }^{70} \mathrm{Ibid}$. , at 123. (Emphasis added.)

7t 180 F. 2d 128 (C.A. 9th, 1950).

72 " $[\mathrm{IIt}]$ is now too late for any federal court short of the Supreme Court to do other than accept [Article of War 94] as valid." Ibid., at 131. It should be noted that the Kronberg case was decided on Feb. 7, 1950. The Uniform Code of Military Justice became effective on
May 5, 1950.

${ }^{73}$ U.S. Const. Art. 1, $\S 8, \mathrm{Cl}$. 13. Consult Snedeker, Jurisdiction of Naval Courts Martial over Civilians, 24 Notre Dame Lawyer 490 (1949).

74 U.S. Const. Art. 1, §8, Cl. 10. Ex parte Quirin, 317 U.S. 1 (1942) (military jurisdiction over espionage by enemy belligerent in time of war).

${ }^{25}$ U.S. Const. Art. $1, \S 8, \mathrm{Cl} .14$.

${ }^{70}$ Ex parte Milligan, 4 Wall. (U.S.) 2, 123 (1866).

77 Myers and Kaplan, Crime Without Punishment, 35 Geo. L.J. 303 (1947). 
been released from the service the "swifter modes of trial" would not appear even remotely-necessary to maintain discipline. Release establishes that a case need not be disposed of speedily on the ground that the person is needed to perform his military duties. Moreover, the initiation of an investigation of criminal charges is sufficient reason for delaying the discharge of a member of the armed services. ${ }^{78}$ From the standpoint of efficiency it does not seem too much to require that military prosecution be foregone unless at least the investigation of an alleged crime is in process. In answer to the argument that some offenses may not come to light for a time, ${ }^{79}$ it can be pointed out that this consideration did not deter Congress from limiting the application of Article 3(a) to offenses not cognizable by the federal courts. ${ }^{80}$

The more cogent arguments in support of Article.3(a) are not, however, that it will enhance discipline. It is evident from the legislative history that Congress enacted Article 3(a) to prevent discharge from operating as a statute of limitations for serious offenses. ${ }^{81}$ Courts-martial jurisdiction was thus extended to resolve a problem only tangentially relevant to the fundamental justification for the existence of courts-martial. Since an equally feasible solution to the problem would have been to place jurisdiction for these offenses in the federal courts, ${ }^{82}$ there would seem to be no constitutional authorization for Article 3(a).

\section{III}

The mere enactment of Article 3(a) raises a presumption that it is necessary to military discipline, and it is perhaps improper for a court to substitute its

${ }^{78}$ C.M.O. 3 (1924); Snedeker, Jurisdiction of Naval Courts Martial Over Civilians, 24 Notre Dame Lawyer 490, 508 (1949).

${ }^{79}$ Kronberg v. Hale, 180 F. 2d 128, 130 (C.A. 9th, 1950). In United States ex rel. Hirschberg v. Cooke, 336 U.S. 210 (1949), the Supreme Court observed that the early version of Article of War 94 was specially designed to punish frauds against the military in connection with the procurement of supplies for the prosecution of the Civil War. A provision directed specifically at frauds against the military was probably necessary at that time because there was no general provision for punishing frauds against the United States. The court in the Kronberg case nevertheless advanced the same argument in 1950 when fraud against the government was clearly within the cognizance of federal criminal jurisdiction.

${ }^{80}$ Since fraud against the United States can be prosecuted wherever committed, United States v. Bowman, 260 U.S. 94 (1922), it appears somewhat ironical that the crime which provoked the passage of Article of War 94 is no longer punishable by the military under Code Article 3(a).

${ }^{32}$ See Hearings before Subcommittee of House Committee on Armed Services on H.R. 2498, 81st Cong. 1st Sess. 617, 800 (1949); H.R. Rep. No. 491, 81st Cong. 1st Sess. 5, 11 (1949); Sen. Rep. No. 486, 81st Cong. 1st Sess. 8 (1949). Probably the most publicized case of this nature was the alleged shooting of an American Army Major in Italy in 1944 by the other two soldiers on an OSS mission. The alleged offenders could not be tried by court-martial because they were discharged before the crime was uncovered. No federal statute gave jurisdiction to the civil courts, and the abrogation of the treaty with Italy during the war prevented their extradition. Although Italy has tried and convicted the two men in absentia, they would appear to be safe from plunishment. Consult In re Lo Dolce, 106 F. Supp. 455 (W.D. N.Y., 1952), 66 Harv. L. Rev. 1136 (1953). United States ex rel. Hirschberg v. Cooke, 336 U.S. 210 (1949).

Myers and Kaplan, Crime Without Punishment, 35 Geo. L.J. 303, 326 (1947). 
judgment of the necessity for such legislation for that of Congress. ${ }^{83}$ Nevertheless, it is submitted that without preliminary procedural safeguards, Article 3(a) should not be permitted to stand.

It is arguable that the political implications inherent in allowing an American soldier, for example, to participate in the murder of a Korean citizen with apparent impunity are such that the military must have the power to demonstrate American justice by recalling the accused to stand trial at the place of the crime. However, the power of Congress to confer courts-martial jurisdiction does not stem from an inclination to assist the State Department. ${ }^{84}$

Sacrificing constitutional guarantees to implement foreign policy seems unnecessary as well as beyond the power of Congress. A nation may impose obligations with respect to the conduct of its citizens outside its territorial limits. ${ }^{85}$ The jurisdiction of federal courts can be constitutionally extended to encompass cases to which Article 3(a) is at present applicable. ${ }^{86}$

Even if the courts permit Article 3(a) to stand, Congress should give careful consideration to this alternative solution to "crime without punishment." Such an alternative has the merit of permitting the punishment of criminal acts committed by United States citizens abroad; and at the same time it clearly preserves the distinction between civilian and military status-a distinction dear to a nation faced with the necessity of maintaining an efficient and powerful military establishment, but properly suspicious of the assertion of military power over civilians.

${ }^{83}$ Stewart v. Kahn, 11 Wall. (U.S.) 493, 506 (1870): The decisions of such questions lie "wholly in the discretion of those to whom the substantial powers involved are confided by the Constitution"; Highland v. Russell Car Co., 279 U.S. 253, 262 (1929): Such decisions are "supported by a strong presumption of validity, and they may not be set aside unless clearly shown to be arbitrary and repugnant to the Constitution."

84 Foreign policy considerations properly enter into the ratification of treaties of extradition. Extradition is, however, subject to judicial supervision. Valentine v. United States ex rel. Neideker, 299 U.S. 5 (1936); In re Lo Dolce, 106 F. Supp. 455 (W.D. N.Y., 1952). (1922).

85 United States v. Blackmer, 284 U.S. 421 (1932); United States v. Bowman, 260 U.S. 94

86 United States v. Bowman, 260 U.S. 94 (1922); Chandler v. United States, 171 F. 2d 921 (C.A. 1st, 1949). The accused can be tried in the district wherein he is found, or is first brought. The Sixth Amendment provision for trial in the "... State and district wherein the crime shall have been committed ..." applies only to federal offenses committed within a state. Cook v. United States, 138 U.S. 157 (1891).

${ }^{87}$ Granting jurisdiction to the federal courts seems never to have been considered by the House subcommittee responsible for Article 3(a); nor does the Senate committee appear to have acted upon this recommendation. Hearings before the Senate Subcommittee of the Committee on Armed Services on Sen. 857 and H.R. 4080, 81st Cong. 1st Sess. 256-57 (1949). It may be that the sole reason for Article 3(a) stems from the consideration of the problem only by the Armed Services Committees, rather than by the Committees on the Judiciary. Military Jurisdiction Over Discharged Servicemen: Constitutionality and Judicial Protection,
67 Harv. L. Rev. 479,491 n. 79 (1953). 